\title{
Subsídios para uma teoria da consciência enquanto cinema com base em António Damásio ${ }^{1}$
}

\section{Elements for a theory of consciousness as cinema, based upon António Damásio}

Luís Carlos S. Branco CLLC/Departamento de Línguas da Universidade de Aveiro, Portugal Icrsb@ua.pt

\section{Resumo}

António Damásio, um eminente estudioso da consciência, que se enquadra no paradigma fisicista darwinista, tem vindo a dedicar-se, ao longo dos anos, ao estudo da consciência, em paralelo com um enfoque especial nos seus componentes emocionais, até chegar à sua obra $A$ estranha ordem das coisas: a vida, os Sentimentos e as culturas humanas, que, de algum modo, constitui o culminar desse seu percurso. Estas suas teorizações sobre a consciência contêm, de modo esparso e não sistematizado, elementos correlatos ao cinema e aos Estudos Fílmicos, que me parecem muito relevantes, sendo uma linha de investigação a aprofundar. Ele, de algum modo, intui essa ligação entre a consignação da consciência humana e os processos cinematográficos, mas não a salienta nem a explora. Ora, eu, com base nas suas postulações, pretendo reunir, sistematizar e expandir uma série de elementos e concepções no sentido de criar um primeiro levantamento crítico para a criação de uma Teoria da Consciência enquanto Cinema. Assim, em paralelo com as advocações damasianas surgirão conceitos de minha lavra, como, por exemplo: introjacente e arquivo imagético interno, entre outros. Este não é, portanto, um trabalho definitivo, mas, sim, exploratório, e deve ser lido e entendido como tal. Pretende-se que seja o primeiro de outros trabalhos que surgirão sobre esta problemática.

Palavras-chave: Teoria da Consciência enquanto Cinema. António Damásio. Filosofia da Mente. A Estranha Ordem das Coisas.

\footnotetext{
1 Este artigo foi realizado com o apoio da Bolsa de Doutoramento em Estudos Culturais da
} Universidade de Aveiro (BD/REITORIA/9316/2020). 


\begin{abstract}
António Damásio, an eminent neuroscientist, who fits into the darwinian physicist paradigm, has been dedicating himself, over the years, to the study of consciousness, with a special focus on its emotional components. From a certain point of view, his book, The strange order of things: life, Feelings and human cultures, is the culmination of his journey. His theorizations about consciousness contain, in a sparse and non-systematized way, elements related to cinema and film studies, which seem very relevant to me and certainly a line of investigation to be deepened. Somehow, he senses this connection between human consciousness and cinematographic processes, but he does not emphasize it or explore it. Therefore, based on his postulations, I intend to gather, systematize and expand a series of elements and concepts in order to create a first critical survey for the creation of a Theory of Consciousness as Cinema. Thus, in parallel with the Damásio's concepts, some of my own will emerge, such as: introunderlying and internal images archive, among others. This essay is not a definitive work, but an exploratory one, and must be read and understood as such. It is intended to be the first of other works that will emerge on this issue.
\end{abstract}

Keywords: Theory of Consciousness as Cinema. António Damásio. Philosophy of Mind. The Strange Order of Things.

\title{
Contextualização prévia de teor crítico ao trabalho de Damásio
}

Antes de adentrar naquilo que é o principal objetivo deste artigo - a criação de uma Teoria da Consciência enquanto Cinema com base nas postulações de António Damásio - será útil contextualizar previamente e vincar o meu posicionamento face ao seu trabalho, no qual detecto concepções muito originais e produtivas e outras, certamente, a merecer as devidas precauções e considerações críticas. Reporto-me, aqui, a toda sua obra, mas com especial enfoque aos seus dois últimos livros ( $A$ estranha ordem das coisas, de 2017, e Sentir \& Saber, de 2020, que constitui uma súmula do anterior), nos quais, as suas teorizações se cruzam, de modo mais evidente, com questões da cultura e do pensamento filosófico contemporâneo.

O pensamento de Damásio tem uma matriz neodarwinista, arraigadamente antropocentrista, que, malgrado a sua faceta humanista, aqui e ali, o impede de ir mais longe. Inova e abre portas conceituais muito interessantes, mas, por causa desses fatores, nem sempre as explora convenientemente. Por exemplo, ele diz que há nos animais prefigurações da Mente Cultural Humana, mas não desenvolve 
esta ideia ${ }^{2}$. Não põe a hipótese, lógica, de que existe uma grande possibilidade de eles, com o processo evolutivo, virem a desenvolver, em toda a sua completude, uma mente cultural. Existem estudos que demonstram que o polvo, o golfinho, algumas aves e símios, denotam um grau inusitado de Consciência. É de crer, portanto, que, no decorrer da sua evolução, desenvolvam mentes avançadas. Nada indica que tal não possa suceder. $O$ neurocientista nunca coloca essa probabilidade, nem a confronta com o seu Antropocentrismo e o seu Neodarwinismo.

Quero realçar também outro aspeto. Ele dá atenção hermenêutica ao trabalho de alguns colegas neurocientistas, mas no referente a outras áreas do saber o seu conhecimento sobre as obras de autores coetâneos é insuficiente. Embora, aqui e ali, refira esporadicamente um ou outro autor coevo, como Steven Pinker ou Manuel Castells, atém-se quase sempre a autores clássicos, como Freud, Hume, Durkheim e Nietzsche. Não perpassam nas suas obras as postulações de pensadores tão relevantes como Zygmunt Bauman, Susan Sontag, Michel Onfray, ou do também discípulo de William James, Richard Rorty. Por sua vez, Michel Foucault e Pierre Bordieu são referidos de passagem, em notas de rodapé. Também Byung-Chul Han, Jürgen Habermas não são referidos. $E$ isto citando apenas alguns nomes com os quais a sua obra teria muito a ganhar se os utilizasse, em especial a última parte do seu livro, $A$ estranha ordem das coisas, onde ele lida com problemáticas da contemporaneidade, como a tecnologia e a organização sociocultural das sociedades pós-modernas, sem nunca confrontar 0 seu pensamento com autores relevantes que se dedicam a analisar esses tópicos.

Por outro lado, e embora incorpore, via autores clássicos, outras áreas de saber no seu trabalho, nomeadamente a Literatura, a Filosofia, a Sociologia e a Psicologia, ele não traz à colação alguns ramos do saber, com os quais o seu pensamento crítico sairia certamente muito enriquecido. Apesar de o tópico fundamental da teoria exposta n $A$ Estranha Ordem das Coisas ser a Cultura, a área dos Estudos Culturais não é referida em lado nenhum. $O$ conhecimento do que já se fez nesse campo daria certamente outra amplitude e enquadramento ao seu trabalho. Repare-se que a definição de Cultura de que ele se socorre é antiquada e completamente desajustada daquilo que, hoje, se entende, de facto,

\footnotetext{
${ }^{2}$ Voltarei a este ponto mais adiante.
} 
por Cultura (ele se baseia numa definição simplista retirada de um dicionário; cf. DAMÁSIO, 2017, p. 29). O estudo de Stuart Hall, Raymond Williams, John Hartley, Tiziana Terranova, James Clifford, entre tanto outros, teria sido muito proveitoso para as suas próprias teses.

Damásio debruça-se sobre as obras de neurofilósofos, como Daniel Dennett e David Chalmers, e se refere a um ou outro autor correlato ao Cognitive Turn, como o caso de Martha Nussbaum, mas não parece estar a par dos estudos e avanços das Neurohumanidades ${ }^{3}$, o que é um pouco incongruente num neurocientista que dá tanta importância à Literatura e à Filosofia e as cruza com a sua área de formação base. Liza Sunshine, Patrick Colm Hogan, Renata Gambino, e neurocientistas como Anjan Chatterjee e Vittorio Gallese nunca são considerados no seu trabalho. A forma como, por exemplo, as emoções, em obras artísticas e literárias, são analisadas por estes acadêmicos é de grande relevo e pertinência e intersecta-se com os estudos que Damásio e a sua equipe têm feito sobre as estruturas narrativas do cérebro. É uma pena que tal não tenha sido ponderado por ele.

Considero a não inclusão da Epigenética, e das suas relevantes conclusões, no seu trabalho, como uma ausência grave. As ideias daí advindas são muito alinhadas com a sua proposta de uma Seleção Cultural evolutiva. É, por isso, muito estranho que não se refira, entre outros, a autores como Conrad Hal Waddington e Robin Holliday, cujos trabalhos têm uma natureza complementar ao seu, e dos quais ele estará certamente a par.

Há também algumas questões de ordem puramente conceitual que gostaria de abordar.

A sua teoria da cultura, baseada na homeostasia, funciona muito bem aplicada ao coletivo, mas não me parece que se possa dizer o mesmo em relação à criação e criatividade do Indivíduo. Note-se que o neurocientista ilustra as suas teses sempre com exemplos de ordem coletiva. Mas será que essas ideias têm validade em casos individuais? São convincentes as demonstrações da aplicabilidade da homeostasia em termos grupais, porém, não sabemos como funciona num contexto individualizado. Eu duvido que os criadores e artistas

\footnotetext{
${ }^{3}$ As Neurohumanidades se constituem como um campo interseccional entre os Estudos Culturais e Literários e as Ciências Cognitivas, no qual neurocientistas e humanistas estudam e analisam obras artísticas e literárias sob o prisma do estudo da mente, das emoções e da consciência.
} 
criem e inventem tendo em vista o bem-estar da sociedade, em que se inserem. Parece-me que o conceito de homeostasia cultural poderia ser menos vago e fornecer pistas importantes sobre a criatividade. Por exemplo, o que é que falta aos artistas, em termos homeostáticos, que os impele a criar? Que equilíbrio homeostático ganham (ou não) dedicando-se às suas obras?

Além disso, a ideia do imperativo homeostático, segundo a qual a humanidade busca sempre, evolutivamente, o equilíbrio, poderia ser conceptualmente expandida e aprofundada. Não será o próprio universo homeostático? Aquilo que sucedeu no imediato pós-Big-Bang não foi algo de caráter homeostático? Podemos até colocar a seguinte questão: o universo tem sentimentos e consciência?

Damásio procura abarcar, nas suas advocações, a quase totalidade das problemáticas relativas aos Estudos da Consciência, mas, na verdade, as soluções que ele propõe nem sempre são satisfatórias e algumas das questões mais importantes continuam, assim, por responder. Sem dúvida que o fato de ele propor a hipótese de que ela está espalhada e imersa no corpo, com vários circuitos e sistemas orgânicos que concorrem para a sua emergência, seja um passo em frente, mas não responde à dura questão de fundo. 0 Hard Problem e o problema da localização da consciência permanecem irresolúveis.

Também as suas explicações sobre os Qualia não são muito convincentes. À semelhança de Daniel Dennett, ele diz que eles não existem. Ora, se estes não existissem também não existiria a subjetividade individual. A sua posição é minoritária no mundo das Neurociências e da Neurofilosofia. Se existissem provas cabais da existência dos Qualia e da separação Mente-Cérebro, isso traria consequências sérias para as ideias que defende e ele está consciente disso. Mas não se pode acabar com o problema do elefante na sala, dizendo simplesmente que ele não está lá, como Damásio faz (adiante, retomarei esta importante problemática).

Damásio diz que a Consciência desponta, a partir do momento em que o Self toma posse das suas Imagens. Fá-lo de modo consistente e consegue persuadir-nos. Mas como é que esse salto efetivamente se dá, em concreto? Como é que se passa a ter autossubjetividade? Esse é um espaço em branco na sua 
teoria. É, aliás, uma questão essencial e em aberto para todos os que se dedicam a estas áreas do saber.

Gostaria, agora, de destacar alguns pontos damasianos que me parecem muito produtivos e relevantes.

Para ele, a consciência não deflui apenas do cérebro, mas do corpo todo, incluindo as vísceras. Assim, o pensamento e a razão não estão separados do organismo que habitam, pois ele também é consciência. A importância conferida ao papel dos intestinos e ao sistema entérico, e às estruturas periféricas, vai nesse mesmo sentido de uma emergência holística da mente. Esta conceção abre, sem dúvida, uma série de possibilidades exploratórias aos neurocientistas e aos filósofos da mente e é um interessante e fecundo ponto de partida.

Deve-se também realçar o fato de ele sobrelevar o fator emotivo e dar importância aos sentimentos, como facilitadores da criação artística e cultural. Não está sozinho nisso. Ele próprio, de certa maneira, já o tinha aventado em obras anteriores. De todo o modo, talvez seja o único a dizê-lo de uma forma tão pertinente e tão bem articulada, inserida no contexto vasto da seleção cultural e da homeostasia sociocultural.

Por fim, ele, de modo não sistematizado, aqui e ali, faz algumas analogias entre o cinema e o despontar da consciência, intuindo, de certo modo, o que ela poderá ter similarmente ao cinema. Ora, este ponto aflorado por ele, mas não desenvolvido nem sistematizado, é o que eu me proponho fazer, aqui, neste artigo. Ou seja, irei fazer um primeiro levantamento crítico sobre as suas teorizações que possam remeter para os Estudos de Cinema, agrupando-as criticamente, e introduzindo alguns conceitos novos, que me permitam criar a base sobre a qual pretendo produzir uma Teoria da Consciência enquanto Cinema.

Para isso, começarei, no ponto seguinte, por referir-me a um dispositivo nuclear, nessa maquinaria cinematográfica da mente: o sistema nervoso. 


\section{O sistema nervoso enquanto facilitador do cinema interno}

O surgimento do sistema nervoso, na história da evolução planetária, alavancou o início da mente cultural, sobretudo por aquilo que Damásio considera uma grande conquista, um verdadeiro salto quântico na linha evolutiva: a capacidade dos organismos de gerarem imagens para si. Estas, coordenadas entre si, possibilitaram a formação de mapas e de úteis e complexas cartografias internas. Ele sintetiza esta questão assim: "A dada altura, (...) teve início a capacidade de mapear os objetos e acontecimentos que eram sentidos" (DAMÁSIO, 2017, p. 111).

Sem este passo, verdadeiramente transformador na evolução humana, não haveria mente, pois uma das suas caraterísticas centrais reside na sua capacidade de representação. Em suma, sem imagens não pode haver consciência. Aproveito para esclarecer que, para Damásio, esta representatividade nada tem a ver com a questão dos Qualia, pois ele, não os reconhece, inserindo-se no paradigma materialista ou fisicalista. Mas, antes de prosseguirmos, analisemos mais detalhadamente esta questão, pois ela é absolutamente central nos Estudos da Consciência.

Os Qualia estão relacionados com o designado Hard Problem da consciência. Ou seja, como é que determinados processos, passíveis de serem mensurados e cientificamente observáveis por terceiros, como é o caso das redes neuronais que se estabelecem ou dos neurotransmissores, dão origem a materiais de ordem subjetiva e pessoal, impossíveis de medir e observar por outrem, como é o caso evidente dos eventos mentais? Repare-se: pode-se registar objetivamente, através da técnicas imagiológicas, a explosão dos neurotransmissores, como a dopamina e a noradrelina, mas não se pode registar nem medir o modo como o medo, a raiva, a euforia, etc., são sentidos por cada um de nós, pois, estas são experiências de índole pessoal e subjetivas. Este é um dos grandes paradoxos que as Neurociências e as Filosofia da Mente ainda não conseguiram deslindar, e estes processos fenomenológicos, intransmissíveis e 
pessoais, designam-se por Qualia, um termo cunhado por David Chalmers, que tem se dedicado ao tal estudo. (Cf. Chalmers, 1996, pp. 231-260).

De algum modo, os Qualia remetem à dualidade cérebro e consciência, e, por isso, por exemplo, Daniel Dennett opõe-se ferozmente a eles (DENNETT, 2017, pp. 360-363), e Damásio também não os aceita. O neurocientista lusoamericano dedica várias páginas a tentar rebater os argumentos de Chalmers. Para ele não existe "O problema 'duro' de que se as mentes surgem do tecido orgânico, pode ser difícil, ou mesmo impossível, explicar como se produzem as experiências mentais, os estados mentais sentidos" (DAMÁSIO, 2017, p. 224). E a solução afigura-se-lhe simples: "Sugiro aqui que o entretecer da atitude perspectiva e dos sentimentos garante uma explicação plausível para o emergir das experiências mentais" (DAMÁSIO, 2017, p. 224).

Sem dúvida que Damásio acrescenta dados e postulações preciosas ao problema da consciência (o facto de a considerar localizada no corpo todo, por exempl(o), porém, no meu entender, nesta questão, não é muito convincente. De que modo se dá, em concreto, a perspectivação? Para ele, basta o "truque da posse", ou seja, a partir do momento em que Eu tomo posse das Imagens e dos respetivos sentimentos emerge a consciência, logo passa a haver Self. Mas, nesse caso, teria de haver um eu antes, pois, caso contrário, não haveria a possibilidade de se tomar posse seja do que for (sem eu não há dono possível). Seriam então os sentimentos a personalizarem-se? O que Damásio sugere é que o eu surge nesse momento: de que modo? Tomando posse das imagens. Mas se não há eu antes como é que tal é possível? É o vazio que toma posse? Ele infere que o eu, a consciência, emerge nesse momento, mas isso é uma contradição em termos. Repare-se: ou havia antes eu, e ele toma posse (e isso, segundo o modelo de Damásio não faz sentido), ou então passa-se de uma identidade vazia, inexistente, para um repentino eu! Mas de que modo, volto a perguntar? A sua explicação, a qual designo por Fiat Lux Neuronal, não responde a perguntas essenciais. Reparese: o fato de eu ter um organismo e um cérebro diferentes daqueles que me leem, não explica, de todo, que eu seja eu e o leitor seja o leitor; ajuda, sem dúvida, a explicar a diferença, mas não a explica, de todo. Para Damásio, o cérebro e sistema nervoso são a consciência; outros, no qual me incluo, são da opinião que o cérebro está relacionado com a mente, mas não é a mente, pois, ela, ao 
contrário do cérebro, é de natureza não-orgânica. Donde, atualmente, é quase unânime considerar a fenomenologia do cérebro correlacionada com a Consciência, mas não de modo direto: para isso, surgiu a designação: Correlatos Neuronais da Consciência (CNC). Mas voltemos às postulações de Damásio, à sua embodied mind, sobre a qual queremos salientar neste artigo os aspetos fílmicos, e à importância que ele atribui às imagens.

Portanto, convém, agora, circunscrever conceitualmente o que se entende, neste contexto, por imagens. Opostamente ao que a palavra parece querer dizer, o seu significado, aqui, não se reporta apenas a representações de ordem visual. Se fosse esse o caso, um cego não teria mente pois não seria capaz de criar representações visuais do mundo externo e interno, o que é sobejamente falso. Assim, as imagens, às quais aqui nos referimos, podem ser de vários tipos: sonoras, olfativas, linguísticas, tácteis, vestibulares, proprioceptivas, e, claro, visuais ${ }^{4}$.

O sistema nervoso facilitou que, para além de sentir e reagir, pudéssemos, através das células nervosas e inerentes redes neuronais, mapear o que sucedia à nossa volta e no nosso interior - aqui reside o despontar da consciência. Sem este cinema Interior, sem estas representações em nós do mundo exterior e interior não haveria mente, dado que ela se funda precisamente nesse feixe de imagens, nessa miríade de mapas sonoros, odoríferos, tácteis e visuais que interagem continuamente entre si. Temos, portanto, literalmente as imagens do mundo dentro de nós.

O resumo de Damásio sobre a capacidade de produzir Imagens, em sequência e interligadas, pelos organismos vivos dotados de sistema nervoso, enquanto pedra de toque da mente cultural, é bastante elucidativo:

\footnotetext{
${ }^{4}$ O Sentido Vestibular é o responsável pela manutenção do nosso equilíbrio e é proveniente de órgãos situados no ouvido interno. Fornece-nos informações preciosas sobre o balanço do corpo e a noção de gravidade. Ajuda-nos, por isso, a locomovermo-nos equilibrados. Por sua vez, o sentido proprioceptivo está, de algum modo, ligado ao sentido vestibular. Ele nos permite perceber a localização, a posição e a orientação do nosso corpo em relação ao espaço. Através dele temos a noção da força exercida pelos nossos músculos e dos movimentos das articulações, sem necessitarmos de utilizar a visão. Ele é o resultado da interação das fibras musculares, que trabalham para manter o corpo na sua base de sustentação, de informações táteis, e do sistema vestibular, localizado no ouvido interno.
} 
As representações produzidas por esta trama de atividades nervosas, os mapas, são afinal o conteúdo daquilo que experienciamos como imagens nas nossas mentes. Os mapas de cada modalidade sensorial são a base da integração que torna possível as imagens, e estas à medida que fluem no tempo, são os componentes das mentes. Na história da existência dos organismos vivos complexos, a presença de imagens constitui um passo transformador (...) As culturas humanas não teriam surgido sem esse passo transformador, sem esta transição espetacular (DAMÁSIO, 2017, p. 112).

A este propósito, o neurofilósofo considera que alguns animais, como as aves e os mamíferos, por possuírem sistemas nervosos de alguma complexidade, são, por isso mesmo, dotados de mentes, ainda que pouco desenvolvidas ${ }^{5}$.

\section{Vísceras e narrativas cinematográficas}

Vejamos, agora, como, ancorando-se no Sistema Nervoso, se processam, montam e editam os filmes internos, que, em última instância, levarão à concreção da Mente Cultural.

Em pano de fundo, existe o que o neurofilósofo denomina por circunjacente do sistema nervoso: ou seja, tudo o que rodeia o sistema nervoso ${ }^{6}$. Por sua vez, o

\footnotetext{
5 Muito se poderia acrescentar sobre esta questão, que constitui atualmente um campo de conhecimento em franca expansão, com notabilíssimos avanços. Talvez não seja descabido afirmar que, em relação à questão da consciência em animais, assistimos, de uns anos para cá, a uma mudança de paradigma. Hoje sabe-se que o tamanho do cérebro é enganador em relação ao grau de desenvolvimento cognitivo e não é, portanto, um critério fiável. A antiga distinção entre animais racionais e irracionais está completamente desajustada em relação aos dados científicos fornecidos pelos mais recentes estudos. Por exemplo, Jennifer Ackerman tem-se dedicado ao estudo das aves com resultados espantosos. Os papagaios e os corvos demonstram uma grande inteligência. Por seu turno, Stephan Linquist e Peter Godfrey-Smith mostram-nos o alto grau de Consciência dos polvos e dos chocos. Mas há muitos mais autores a dedicarem-se a tópicos similares, entre eles, Sy Montgomery e Frans de Wall. (Cf. Ackerman, Jeniffer. The genius of birds. New York, London: Pinguin Books, 2017. /Cf. Godfrey-Smith, Peter. Outras mentes: o polvo, o mar e a origem profunda da consciência. Trad. de Pedro Garcia Rosado. 2. ${ }^{a}$ ed. Lisboa: Temas e Debates/Círculo de Leitores, 2017. /Cf. Sheldrake, Rupert. Dogs that know when their owners are coming home: and other unexplained powers of animals. New York: Three Rivers Press/Random House, 2011.)

6 o conceito de circunjacente é explicitado pelo próprio Damásio quando diz: "Aquilo que rodeia um sistema nervoso, o seu circunjacente, é extraordinariamente rico (...) inclui o mundo exterior ao organismo (...) inclui ainda o mundo dentro do organismo" (DAMÁSIO, 2017, p. 113). Mais adiante, o neurocientista detalha esta noção, dividindo o circunjacente em dois planos: o mundo interior visceral e o mundo referente à pele e ao sistema muscular e esquelético, ambos rodeando - sistema nervoso. Para estes componentes, criei de minha lavra os seguintes termos: circunjacente externo e introjacente.
} 
circunjacente é constituído por dois componentes. $O$ primeiro consiste no mundo fora do organismo: o exterior a nós com o qual nos relacionamos. O segundo é o mundo dentro do organismo, o nosso interior corporal. Chamemos ao primeiro circunjacente externo, e ao segundo introjacente (ou circunjacente interno). Por conseguinte, este quadro circunjacential possibilitou a importante existência de representações internas do mundo exterior e também do mundo interior, nos organismos vivos, nos nossos corpos.

Com o decorrer da evolução neurobiológica, aduziu-se a esta rede interligada de imagens internas um elemento deveras importante, a narração: "Era agora possível associar imagens de forma a que elas narrassem ao organismo acontecimentos que lhe eram tanto internos como externos" (DAMÁSIO, 2017, p. 114). Devo, aqui, salientar alguns pontos que me parecem importantes. Por um lado, o neurocientista insere esta emergência da narratividade num longo processo evolutivo, que só se torna evidente quando, em especial nos mamíferos, surgiu a maquinaria do sistema nervoso. Por outro, naquilo que se afigura, para mim, o dado mais relevante deste ponto das postulações de Damásio, é que esta narratividade diz respeito ao corpo, às vísceras - é aqui o seu início. Se quisermos ir um pouco mais longe, podemos dizer que a nossa capacidade ficcional, enquanto espécie, advém daqui, da apreensão da consciência, quiçá num estado ainda inicial, através das ocorrências corporais, nas quais ela está embodied, imersa. Aliás, as importantes experiências sobre componentes narrativos no cérebro, realizadas por Damásio e pela sua equipe, corroboram, de algum modo, esta sua intuição, que, no meu entender, está certa (Cf. Damásio et al., 2007). Consciência e corpo estão interligados, como gêmeos siameses, xifópagos, e comunicam e conjugam-se através de processos narrativos. Por exemplo, a dor no corpo que, através dos sinais emitidos pelo sistema nervoso e sentimentos associados, a consciência apreende é um dado narrativo no seu emergir.

Assim, essa narração, ou se quisermos, este elemento autonarrativo, ocorre do seguinte modo. A partir das imagens do circunjacente interno, mais especificamente das vísceras e da circulação sanguínea, que configuram os processos de química metabólica mais antigos, emergiram os sentimentos. Em contiguidade, com base nas imagens internas da estrutura esquelética e dos músculos, foi possível uma autorrepresentação literal do corpo e do seu lugar no 
mundo; aquilo a que Damásio chama "a representação envolvente de cada vida" (DAMÁSIO, 2017, p. 114). Claro, que devemos encarar isto no âmbito das advocações de Damásio, tendo em consideração que não é lícito que, de facto, seja assim, e cotejando-as com outras teorizações. Por exemplo, para Damásio a consciência emerge; mas para John Searle ela é sobreveniente, o que implica uma bottom up causation: a consciência emerge, assim, de cima para baixo - os vários elementos cerebrais conjugados impelem a configuração da mente (cf. SEARLE, 2020). E para Chalmers não existe sequer emergência da consciência, pois, para ele, há uma contradição inerente entre a fisicalidade e os eventos mentais. Logo, a consciência, cuja essência advém da autossubjetividade, não pode ter origem em quaisquer componentes físicos (neste caso, o cérebro) (Cf. CHALMERS, 1996). Seja como for, é de relevar o esforço feito por Damásio no sentido de nos chamar a atenção para a correlação entre a consciência e os processos corporais. Dito de outro modo, a consciência existe em interligação com o corpo. Estamos, aqui, no plano da senciência, do sentir subjetivado. $E$, a mim, interessa-me, particularmente, sobrelevar e sistematizar aquilo que se pode, no meu entender, considerar como um cinema inter-relacional entre corpo e mente. Continuemos, então, a avançar nessa senda.

Portanto, essas duas novidades referidas por Damásio, o surgimento dos sentimentos e a autorrepresentação espacial (interna e externa), alavancaram, como veremos melhor ao longo deste artigo, a emergência do nível mais alto do ser: a consciência.

\section{Dispositivos de filmagem interior e seus cenários: os dois mundos e os Portais Sensoriais}

O sistema nervoso tem ao seu dispor uma profusa maquinaria, de natureza fílmica, que lhe permite a criação imagética e o mapeamento de objetos e acontecimentos nos quais o corpo está envolvido. Utilizo, aqui, a palavra "acontecimentos", de modo contíguo ao senso comum, e remeto a sua problematização para a consulta de outros autores. Por exemplo, John Searle, que 
é um interessantíssimo autor, pois, por um lado, é um fisicalista, por outro, está próximo das interrogações metafísicas de Chalmers, dedica uma parte do seu pensamento crítico à ambígua questão da intencionalidade e diferencia entre o que é a satisfação de uma intenção (por exemplo, levantar o braço para coçar o rosto) e o que é uma ação, que se compõe da intenção na ação e o movimento corporal (SEARLE, 2020, pp. 91-147). Mas poderíamos também remeter a Deleuze, em paralelo com Leibniz, no qual a noção de acontecimento é central, sobretudo, na sua obra Lógica do sentido, mas não só, considerando-o um incorporal, um efeito de superfície, e antepondo-lhe o querer.

Voltemos ao corpo. A retina e o ouvido interno, ambos com ligação ao córtex cerebral, as terminações nervosas da pele, que nos permitem apreender todas as nuances do tato, bem como o olfato e o paladar, enfim, todos estes dispositivos de mapeamento contribuem, num fluxo constante, para a fabricação ininterrupta de imagens internalizadas. Como postula Damásio, estas são constituídas pela vasta gama de imagens do circunjacente externo e pelo interno. Este último, o circunjacente Interno (ou introjacente) fornece-nos imagens do mundo interior não tão antigo e do mundo interior mais antigo.

O mundo interno mais antigo diz respeito à homeostasia básica, ${ }^{7}$ que se consubstancia, sobretudo, nas vísceras e no seu metabolismo químico. Assim, o coração, os intestinos, os pulmões, a pele, que é na verdade a maior das nossas vísceras, os músculos lisos, etc., são componentes essenciais desse mundo. E nós estamos, de fato, a mapeá-lo constantemente, pois, produzimos um fluxo contínuo de imagens, que nos permite perceber, por exemplo, se temos azia, cólicas, desconforto corporal, fadiga, febre, entre outros estados internos. Damásio

\footnotetext{
${ }^{7}$ A Homeostasia é o princípio de autorregulação orgânica, que se configura no controle da tensão arterial e da temperatura corporal pelo organismo. Ela é imprescindível para o bem-estar e para a regulação vital do Ser Humano. No entanto, António Damásio, no que é uma das originalidades do seu pensamento crítico, expandiu sobremaneira este conceito, colocando-o como principal impulsionador da Consciência Humana e das suas produções artístico-culturais. Assim, aquilo que ele designa por Imperativo Homeostático Sociocultural impele, por um lado, à Sobrevivência e à Persistência. O Ser Humano tende a resistir e a lutar por durar o mais que possa, ou, por outras palavras, a tentar adiar a morte e viver, até lá, do melhor modo possível. Por outro lado - e é aqui que Damásio procede a uma extrapolação original -, além do mero bem-estar do organismo, a Humanidade está talhada para prevalecer, dominar e florescer. E, em ambas estas vertentes da Homeostasia, quer na orgânica, quer na civilizacional, os Sentimentos são muito relevantes, pois operam como adjuntos mentais da Homeostasia. Foi isso que, segundo Damásio, conduziu ao despontar e florescer de todas as áreas do conhecimento e criação humanos. (cf. DAMÁSIO, António $A$ estranha ordem das coisas: a vida, os sentimentos e as culturas humanas. Trad. de Luís Oliveira Santos/João Quina Edições. 1. ${ }^{a}$ edição. Lisboa: Temas e Debates/ Círculo de Leitores, 2017).
} 
entende que é partir daqui, do mapeamento imagético do nosso mundo visceral, do nosso mundo interno mais antigo, que emergiram os sentimentos. Claro que é visível aqui a posição materialista e darwinista do neurocientista e ela é altamente discutível, sobretudo, se a remetermos para o âmbito da Filosofia da Mente. Para ele, os sentimentos ocorrem a partir dos eventos corporais, mas devemos interrogarmo-nos se, de fato, é assim, e se não há sentimentos que, porventura, ocorram sem a intervenção do corpo, como é o caso evidente dos sentimentos estéticos e/ou abstratos. A posição dele é reducionista. Nem todos os sentimentos se reportam ou derivam do organismo e pode suceder até o contrário: os sentimentos podem influenciar o corpo e mesmo a saúde - esta influência dos estados mentais no organismo, hoje, aliás, está mais do que comprovada e contradiz as postulações de Damásio.

Segundo as suas postulações, por sua vez, o mundo interior não tão antigo constitui-se com base no esqueleto e nos músculos esqueléticos. É através deles que dançamos, falamos, escrevemos, corremos, etc. Ele está relacionado com os nossos movimentos, as nossas ações voluntárias ${ }^{8}$, ao passo, que o mundo interior mais antigo se refere às nossas ações internas, automatizadas. Repare-se: não precisamos dar uma ordem mental ao coração para ele bater, ao passo que, por exemplo, para teclarmos um computador ou tocarmos guitarra já temos de o fazêlo.

Damásio procura esclarecer-nos com a seguinte analogia. O mundo interior não tão antigo funciona como um exoesqueleto, uma armadura que envolve e protege o mundo interior antigo, que é, por excelência, um mundo de valência, de julgamento e monitorização constante. A nossa própria vida depende literalmente dele, do seu bom estado e funcionamento.

Para que, através do mapeamento imagético, tudo isso seja devidamente escrutinado internamente existem umas espécies de câmaras, de natureza fílmica e multimidia, das quais o nosso organismo se serve. São os, assim denominados, portais sensoriais. Estão umbilicalmente ligados aos sentidos e ao modo como percecionamos os circunjacentes. Por conseguinte, na nossa cinematografia

\footnotetext{
${ }^{8}$ Esta questão das ações não cabe no âmbito deste artigo e é aqui utilizada de modo meramente ilustrativo. Aliás, ela remete para a das mais importantes questões no contexto dos Estudos da Consciência, na qual vários autores têm trabalhado: a intencionalidade e, em interligação, o funcionalismo. É o caso de John Searle, que é contra, e Hilary Putnam, que já foi a favor e, hoje, contesta as suas premissas.
} 
interna, os nossos gravadores e as nossas câmaras são: as órbitas dos olhos, os ouvidos, o nariz, as papilas gustativas e a pele.

Sublinhe-se que os processos ocorridos nos e através dos portais sensoriais são holísticos e multiformes. $O$ ato de ver, por exemplo, relaciona-se, para além dos olhos, com a musculatura do pescoço e com o córtex e a memória. Ou seja, a consciência está, inegavelmente, ligada aos processos perceptuais, num dialogismo constante. Neste sentido, as suas postulações são originais, pois, não parece haver, na sua teorização, uma separação entre mente e corpo, mas sim uma interligação nodal, como, aliás, tenho vindo, paulatinamente, a demonstrar ao longo deste artigo. Note-se que essa ligação é profundamente cinematográfica. Assim, a consciência não se separa verdadeiramente dos filmes, das narrativas imagéticas-corporais, defluentes dos órgãos sensoriais, pois, não só interage com eles, bem como, ela própria faz parte intrínseca desse processo senciente. Não são apenas os olhos que vêm; é também a consciência, pois, no ato de ver, ela está também implicada. Este diálogo criativo, que ocorre, em primeira mão, no imo do corpo, é um dos pontos mais originais e entusiasmantes na teoria damasiana. E nisso se distingue de todos os outros materialistas. Repare-se que ele não dá apenas importância ao encéfalo e ao sistema nervoso, mas também, por exemplo, ao sistema entérico. A consciência está, se quisermos, espalhada pelo corpo todo. Ou, e embora ele não o diga, eu acho que a consciência, em grande medida, é o corpo todo (poderá ser mais do que isso e esse é um dos temas que analisarei em trabalhos futuros, contudo, o que referi é um ponto de partida). Mas isto conduz-nos, inevitavelmente a uma série de questões que não cabem no contexto deste artigo, mas poderão ser exploradas em trabalhos futuros: corpos diversos implicam consciências diversas? Se a consciência afeta, como já referi atrás, a saúde, de que modo é que tal se processa e como isso se relaciona com a sua imersão circunjacential do corpo? É ela, neste contexto, fenomenal ou epifenomenal? 


\section{Guião do filme mental e autonarratividade}

Aqui chegados, podemos fazer a seguinte pergunta: afinal, o que faz a mente com essas imagens, o que o mundo interior mais antigo e o mundo interior não tão antigo, em interação com o sistema nervoso, e usando os respetivos dispositivos, incluindo os dispositivos sensoriais, lhe fornecem? A resposta é simples e de consequências vastas: a mente usa essas imagens para (nos) contar histórias. A natureza do nosso pensamento é arraigadamente narrativa. É constituído por um constante fluxo narrativo. A nossa mente é como um velho contador de histórias que, até ao nosso último momento, narra, por assim dizer, ad infinitum. Atenção, não devemos aqui confundir as propostas damasianas com a Teoria dos Rascunhos Múltiplos, de Daniel Dennett, segundo a qual não existe eu, enquanto entidade subjetiva, sendo que este, o self, é uma ilusão criada pelo cérebro, através do uso e replicação de memes, que, para ele se constituem como equivalentes mentais dos genes, o que é, no meu entender, uma posição pouco sólida. Embora possa haver influência, os eventos mentais e os genes são de natureza diferente; confundir as suas propriedades parece-me um raciocínio não consequente (aliás, a epigenética tem demostrado à saciedade que os genes estão longe de serem determinantes). E, já agora, porque não poderia suceder o inverso: os genes serem uma réplica dos memes mentais? Dennett considera que há uma continuidade de rascunhos neuronais e que é deles que advém, segundo ele, a ilusória sensação de consciência. Pergunto, assim sendo, as ideias que ele propõe devem ser levadas a sério quando vêm de algo que não existe (a sua consciência)? $E$ algo que não existe, apenas simula a existência, é sequer concebível? Como coaduna ele, por exemplo, as suas teorias com os relatos de crianças que nasceram sem cérebro e, no entanto, choraram e demonstraram ter emoções? Outra ilusão, outro simulacro? Para este filósofo, a consciência, é, portanto, um mero acumulador de informação. Assim, o ser humano recebe inputs, sinais exteriores, através dos quais se autorrepresenta e o eu é o centro dessa narrativa. Ele considera, portanto, que a Consciência funciona algoritmicamente. Contudo, parece-me que o cérebro humano funciona de modo seletivo, não algorítmico, e esse modo de funcionar é subjetivo e pessoal, e nisto estou de acordo com Damásio, que reconhece importância aos algoritmos, mas também aponta as suas 
limitações, sobretudo, quando se trata de um campo altamente subjetivo e qualitativo, como é o da consciência. Além disso, ao contrário da mente humana que se move num universo simbólico e numa rede cruzada de referenciais semióticos, os computadores são capazes de gerar resultados a partir da sintaxe, mas não da semântica, como tentou demonstrar John Searle com a alegoria d' $O$ Quarto Chinês. Retomemos a nossa teoria cinematográfica da consciência.

Nas postulações de Damásio, o modo como esse precioso guião mental é delineado e executado é delicado e minudente. Nele entram dois elementos fundamentais sem os quais não é possível a criação de quaisquer narrativas: a memória e as palavras. Sobre a importância destas últimas, o médico neurologista faz a seguinte apreciação: "A incessante tradução em linguagem de toda $e$ qualquer imagem que nos cruze a mente será, porventura, o modo mais espetacular de enriquecimento da mente" (DAMÁSIO, 2017, p. 135).

A mente coordena e liga todas essas Imagens entre si, ligando diversos elementos, provenientes de várias partes, formando, deste modo, uma cadeia de pensamentos, que mais não é do que uma narrativa integrada. Em termos neurofisiológicos, os córtices associativos desempenham aqui um papel importante de interligação, em especial o Default Mode Network'.

Assim, tal como um realizador, a mente corta e acrescenta, edita e manipula as Imagens e as traduz em linguagem ${ }^{10}$. Há uma incessante tradução das Imagens que lhe chegam em linguagem, em discurso.

${ }^{9}$ O Default Mode Network consiste num conjunto de estruturas cerebrais, que Damásio e a equipe de cientistas que trabalha com ele, no Brain and Creativity Institute, conseguiram identificar, que formam uma arquitetura neuronal narrativa. Fizeram-se experiências narrando histórias a vários sujeitos, que falavam línguas diferentes. Através de métodos observacionais imagiológicos do córtex, percebeu-se haver estruturas universais, correlatas aos relatos narrativos, no cérebro humano. Ora, este estudo empírico representa um enorme passo em frente e confirma uma série de hipóteses aventadas por vários autores desde há décadas (caso de Walter Fisher e outros). Saliento o fato de estas estruturas narrativas cerebrais estarem situadas em zonas cerebrais mais nobres do que as relacionadas com a Semântica. A esse propósito, o mencionado artigo coletivo nos diz que "These results demonstrate that neuro-semantic encoding of narratives happens at levels higher than individual semantic units and that this encoding is systematic across both individuals and languages." (DAMÁSIO; Kaplan; Man, 2017, p. 1).

Esta descoberta, da equipe liderada por Damásio, é de uma extraordinária importância, pois, consubstancia o que uma série de pensadores já vinham, de diversos modos, a postular há muito tempo. Ou seja, a importância do storytelling na evolução humana e de como o Sistema Nervoso e o cérebro humano são, por natureza, narrativos. Entre esses autores contam-se Patrick Colm Hogan, David Herman e Nancy Easterling. (Cf. HOGAN, 2003, 2003a./ HERMAN, 2003, 2013. / EASTERLIN, 2013).

10 Existe, aqui algum paralelismo com outro darwinista, Daniel Dennett, ao qual já me referi criticamente, em parágrafos anteriores. Além disso, poderíamos também correlacionar estas ideações de Damásio com autores correlatos ao Cognitive Turn, que ocorreu, a partir dos anos 90, 
Além disso, essa brilhante cineasta, que é a mente, forma novas imagens, com base nas que lhe são fornecidas e estrutura-as num Elo Sequencial: "no início, as imagens originais são importantes por si próprias e como alicerce da vida mental. Contudo, a sua manipulação pode levar a derivas novas" (DAMÁSIO, 2017, p. 135). Ou seja, temos aqui configurada a capacidade de abstração, de gerar imagens abstratas. A partir do arquivo imagético ao dispor nos Mundos mencionados anteriormente, em um remix interno, gera-se a mais difícil e subjetiva tipologia de imagens, as Abstratas.

\section{Memória e remix de imagens}

Com base nas Imagens, constrói-se igualmente a memória. Esta começou por ser, sobretudo, de ordem química e permitia aos organismos vivos reconhecer outros. Era, portanto, uma ferramenta de sobrevivência essencial. Aliás, ainda hoje a memória é essencial à sobrevivência. Vejamos, então, de que modo ocorre essa relação simbiótica entre imagens e memória.

Quando o Sistema Nervoso coordena as Imagens de ambos os mundos, referidos nos pontos anteriores, isto gera um determinado código neuronal. A grande particularidade é que esse código pode ser reativado em qualquer altura; pode ser played back. As imagens, de diversa ordem e tipologia, podem, por isso, ser percepcionadas de novo. É o que sucede quando recordamos um determinado evento; imaginemos, por exemplo, uma experiência traumática qualquer e a sua recordação. A constituição da memória depende, assim, dessa capacidade de reativação das Imagens Interiores, através dos respetivos códigos neuronais iniciais. Claro que este processo é mais complexo do que Damásio propõe. Se, por um lado, me parece que ele tem razão, que a memória está ligada a determinadas redes neuronais e à sua posterior reativação; por outro, há uma série de perguntas por responder: sucede o mesmo, por exemplo, nas memórias ocultas, e o que sucederá, por exemplo, no caso das memórias falsas, e, já agora, o que muda efetivamente entre o momento em que algo é registado mnemonicamente e

nos Estudos Literários e Culturais, entre os quais: Paul B. Armastrong, David Lodge e Patrick Colm Hogan. 
- momento em que, mais tarde, recuperamos essas memórias. O que lhes aconteceu, o que foi elidido e/ou acrescentado, de que modo e porquê?

Em termos neurofisiológicos, segundo Damásio e outros neurocientistas, o hipocampo assume uma importância matricial nestes mecanismos de rememoração. Ele permite a integração de imagens no todo da mente. Assim, a sua perda implica que, por exemplo, continuemos a reconhecer uma casa, mas a deixemos de reconhecer como nossa. O neurocientista diz-nos "O hipocampo é essencial para a produção do mais elevado nível de integração de imagens codificadas. (...) também permite a conversão de codificações temporárias em codificações permanentes" (DAMÁSIO, 2017, p. 138).

O hipocampo, sobre o qual unanimemente se considera desempenhar um papel nodal nos processos da memória e na aprendizagem, funciona, assim, como um selecionador e um editor de imagens. Daí que ele seja a parte mais afetada na Doença de Alzheimer. É nele que ocorre uma parte importante da neurogênese, a importante produção de neurônios novos e a criação de novas memórias. Este processo de fixação de memória é-nos explicado nos termos seguintes ${ }^{11}$ :

As imagens que correspondem a uma narrativa verbal $\mathrm{e}$ as imagens que correspondem a um conjunto de movimentos relacionados ocorrem frequentemente a par na experiência em tempo real, e embora as respetivas memórias sejam criadas e armazenadas em sistemas diferentes, elas podem ser recordadas de forma integrada. Cantar uma canção com a respetiva letra exige a integração sincronizada de vários fragmentos de recordação: a melodia que orienta a canção, a memória das palavras, as memórias ligadas à execução motora. (DAMÁSIO, 2017, p. 139).

\section{A mente cultural e imagens do porvir}

O raciocínio está intimamente conectado com a memória e as imagens. De que modo? Ele interage e coordena as imagens presentes (que se reportam ao que está a acontecer no agora) e as imagens recordadas. Interagindo com ambas,

${ }^{11}$ Acrescente-se o dado seguinte. $O$ stresse influencia substancialmente a neurogênese (a criação de novos neurónios no cérebro) e a formação da memória. 
a razão antecipa, ou tenta antecipar, o futuro. E aqui, neste processo interno de antevisão, de imaginarmos o futuro, emerge a imaginação. Com base em imagens recordadas e imagens presentes, criamos imagens do porvir. Detalhemos esta ocorrência, salientando que esta, como é evidente, é complexa e holística. Quando pretendemos, nos nossos pensamentos, projetarmo-nos no futuro (um exemplo simples: "Amanhã, vou comprar aquele pão maravilhoso da Dona Rosa"), fazemolo estribando-nos em memórias do passado (os vários pães que já comemos, o sabor, o cheiro, o aspeto, ou seja as imagens do pão da Dona Rosa), e imaginamo-nos a ir comprá-lo, antevendo o dia seguinte (criamos esse filme futurista na nossa mente, onde nos percepcionamos a ir comprar o pão da Dona Rosa). Chamo a atenção que estas diversas fases e elementos ocorrem quase em simultâneo e em interligação.

Isto tem sido absolutamente essencial para a evolução da civilização e cultura humanas. Este processo inter-relacional entre memória, antevisão do futuro e ulterior criação está na base da invenção e criação humana. Por exemplo, sem a memória do Sol, que é um círculo, não se teria descoberto a roda, e sem a recordação desta, mais tarde, não se teria inventado o carro, etc. $O$ processo que ocorre ao imaginarmos o saboroso pão da Dona Rosa é similar, ainda que com outro grau de complexidade, ao das grandes invenções humanas. Pensemos nas catedrais barrocas e nos seus arquitetos. Entre outras coisas, basearam-se nas memórias de animais serpentiformes e na memória do brilho do ouro para imaginarem (anteverem) uma nova forma de templo. "A recordação de imagens passadas é essencial para o processo de imaginação (...) As imagens recordadas são ainda essenciais para a construção de narrativas (...) A recordação afina o significado dos fatos e ideias associados aos diversos objetos e acontecimentos", diz-nos Damásio (2017, p. 140). Foi desse modo que a consciência se concretizou em mente cultural, concretizando aquilo que criou, primeiro, em um futurista filme mental.

Estamos, portanto, incessantemente a contar e a cruzar histórias a nós mesmos, recriando-as e interrelacionando-as umas com as outras, e misturando os diversos tempos internos. Um mesmo fato narrativo da nossa vida tem, obviamente, diferentes interpretações consoantes à ordem de introdução dos objetos e acontecimentos e a natureza e magnitude da sua descrição no processo 
rememorativo. É por isso que, com a passagem do tempo, vemos os mesmos acontecimentos de prismas, por vezes, antitéticos. Portanto, e tendo também em consideração o importante papel do inconsciente e da imprevisibilidade neuroquímica cerebral, podemos dizer que a nossa consciência vai selecionando, momento a momento, o que relevar e o que ocultar e esbater no arquivo imagético da nossa memória, do qual ela se vai servindo. Assim, a mente funciona como um motor de busca, um search engine, que acede a memórias passadas, a pensamentos passados e imagens antigas, e constrói, a partir delas, imagens e memórias novas, que, depois, a mente regista. $O$ processo criativo funciona de modo similar:

Esse processo imaginativo, o qual, por si só, é uma mistura complexa de pensamentos atuais e de pensamento antigos, de novas imagens e de imagens antigas, está constantemente a ser memorizado. $O$ processo criativo está a ser registado para um uso futuro possível e prático (DAMÁSIO, 2017, p. 141).

Note-se que o próprio ato criativo, seja ele pintar um quadro ou realizar um filme, vive da conjugação do saudável equilíbrio, em vários níveis, do passado e do futuro. Ou mais concretamente: vive das imagens recordadas e das imagens projetadas adiante no tempo. $\mathrm{Na}$ arte e cultura, tenta-se presentificar o passado; quem realizou uma obra de arte fê-lo no intenso presente, com a memória em pano de fundo, mas igualmente visando o futuro. É isso que, por exemplo, acontece sempre que encenamos uma peça de Shakespeare, e foi isso certamente que the sucedeu quando as escreveu: presentificou o passado e projetou-o no futuro.

\section{Sentimentos e cinema da memória}

Nesse mesmo contexto, Damásio interroga-se também sobre um fenômeno complexo: a recriação de sentimentos através da memória. Ou seja, a capacidade que, ao rememorarmos um determinado evento, temos de, por um lado, alterar 
sensorialmente essas ocorrências passadas, tornando os pormenores descritivos mais nítidos e vivos, e, por outro lado, a capacidade de voltarmos a sentir o que sentimos no passado, reavivando-o. Donde se infere que o processo de rememoração é, essencialmente, um processo criativo, imaginativo. Esse ato de recriação dos sentimentos passados, invocando ocorrências antigas, é feito cinematicamente, através de montagens e edições internas; a memória vive, assim, de ajustes criativos.

O modo como realizamos e editamos cinematograficamente a memória condiciona a forma de como iremos sobreviver ao futuro. Recorrendo aos exemplos extremos dos suicídios de Primo Levi e de Paul Celan, podemos dizer que lhes foi mais penosa a memória dos hediondos campos de concentração do que a própria estadia lá. Ambos sobreviveram estoicamente ao Holocausto, mas não resistiram à sua recordação, à recriação interna dos Sentimentos e acontecimentos lá passados. Um exemplo oposto; a obra de Viktor Frankl atesta uma rememoração e recriação altamente positiva de eventos insuportavelmente dolorosos ${ }^{12}$.

Resumindo, a memória é certamente uma das pedras de toque da criação. Não há arte nem cultura sem representações ou recriações mnemônicas: "A forma como criamos culturalmente e aquilo que criamos bem como o modo como reagimos aos fenómenos [sic] culturais, dependem dos truques das nossas memórias imperfeitas, e da forma como os sentimentos as manipulam" (DAMÁSIO, 2017, p. 199).

Deduza-se, portanto, que a manipulação da memória está sempre presente no ato criador. Não existem criadores amnésicos, pelo contrário, na sua grande maioria, demonstram ter uma verdadeira memória de elefante.

12 Cf. Frankl, Viktor E. Man's search for meaning: the classic tribute to hope from the holocaust. London: Ebury Publishing/Penguin Books, 2004. 


\section{Subjetividade e integração das experiências}

Depois das imagens, e respectivos sentimentos, e da memória, o circuito de formação da consciência individual completa-se com dois aspetos cruciais: a subjetividade e a integração das experiências.

Ao tentarmos definir a subjetividade, podemos correr o risco de entrarmos em conceções paradoxais, mas Damásio é muito objetivo nessa definição. Ele parte das imagens correlatas, quer ao mundo interior antigo, quer ao mundo interior não tão antigo, quer ao circunjacente externo e ao introjacente, para nos demonstrar que a subjetividade, que é sempre de natureza processual e não reificada, emerge no momento em que o sujeito toma posse dessas mesmas imagens.

Há dois componentes a ter em conta nesse processo de apropriação das imagens: os sentimentos, que acompanham as imagens, e a perspectivação. Por outras palavras, as imagens são tomadas pelo sujeito de modo único e personalizado, pois, estão ligadas a sentimentos próprios. Isto origina uma perspectiva individual sobre essas imagens. É deste modo que surge a autossubjetivação, o aparecimento do sujeito subjetivado, o eu de cada um. Sublinhe-se também a natureza ontológica da subjetividade. Ela é de tal modo importante que sem ela o ser desvanece-se como pó no ar:

Em circunstâncias patológicas, quando a subjetividade desaparece - quando as imagens na mente deixam de ser automaticamente reivindicadas pelo seu dono/sujeito legítimo -, a consciência deixa de funcionar de modo normal. Se nos impedirem de inspecionar o conteúdo da mente numa perspectiva subjetiva, esse conteúdo fica à deriva, sem pertencer a ninguém especificamente. Quem saberia da sua existência? A consciência desapareceria, o mesmo acontecendo ao significado do momento. A sensação de ser ficaria em suspenso (DAMÁSIO, 2017, p. 209).

Vejamos, agora, como funciona a integração experiencial. A autoperspectivação e a geração de sentimentos só são verdadeiramente situadas 
com a respetiva integração das experiências no todo do sujeito. Essa ordenação, de natureza qualitativa e gradativa, constitui a integração experiencial.

Mas podemos questionar onde e de que modo se produz essa integração, qual é, afinal, esse quadro mais vasto a que Damásio refere? Na verdade, não existe nenhuma região em específico, no organismo e no córtex, onde tal processo ocorra, pois, ele é de natureza holística. São várias as regiões do corpo e do sistema nervoso que participam ativamente no processo consciencial. Todas elas concorrem para a integração experiencial, na qual, por um lado, se ordenam as imagens narrativamente, e por outro, essas mesmas imagens são coordenadas entre si. "O processo relacionado com a integração de experiências exige a ordenação de imagens em forma de narrativa e a coordenação dessas imagens com o processo de subjetividade" (DAMÁSIO, 2017, p. 217).

Julgo, por isso, que integração experiencial consiste mais numa série televisiva do que propriamente num filme. Assim, a emergência da consciência não parece consistir num só filme, mas em vários, porventura até diferentes, mas interligados e ordenados entre si.

\section{Súmula e considerações finais: 0 cinema da consciência $^{13}$}

Neste último ponto, gostaria de fazer uma breve súmula do que foi sendo tratado ao longo do artigo, e de salientar alguns aspetos no sentido de consolidar a concepção damasiana da Consciência, enquanto fenômeno de natureza eminentemente cinemática.

É, mais ou menos, unânime, entre a comunidade científica, considerar a Consciência como um estado mental em que estamos acordados, alertas e vemos

${ }^{13}$ A consciência é uma temática difícil, onipresente em todos os livros de Damásio. De obra para obra, ele procede a atualizações e acrescenta dados e novas interpretações. $O$ seu entendimento da noção de Eu, de Self, vai evoluindo a cada novo livro. Aliás, n'A Estranha Ordem das Coisa, sucede isso mesmo, quando surge com um conceito novo no seu trabalho, contíguo ao de consciência: a mente cultural. (Sobre a conceção e os mecanismos da consciência consultar, em especial, as seguintes obras de António Damásio: $O$ sentimento de si: corpo, emoção e consciência. Versão portuguesa a partir do original em inglês revista e anotada pelo autor. 1. ${ }^{a}$ edição. Lisboa: Temas e Debates/Círculo de Leitores, 2013. [1999]; O livro da consciência: a construção do cérebro consciente. Trad. de Luís Oliveira Santos/João Quina Edições. 1. ${ }^{a}$ edição. Lisboa: Temas e Debates/ Círculo de Leitores, 2010.) 
as coisas com clareza (em estado de coma ou anestesiados não estamos conscientes) ${ }^{14}$. A este propósito, o médico neurologista afirma que "Se observarmos juntos a mesma cena, reconheceremos de imediato que temos perspectivas diferentes" (DAMÁSIO, 2017, p. 199). Ora, isso sucede deste modo porque cada um de nós tem a sua própria consciência, o seu próprio ponto de vista. A consciência é um estado mental que permite ao seu dono experienciar em privado, e de modo singular, o mundo ao redor, externo e interno, e, simultaneamente, aspetos do seu ser. Tal não é possível sem imagens e sentimentos, que são elementos centrais na configuração da consciência. Note-se que nas doenças em que há uma notória perda do grau de consciência o que fica difusa e se perde é essa recolocação e integração dos sentimentos e das imagens, e, por exemplo, como sucede no caso do Alzheimer, há uma presentificação de imagens que deveriam ser apenas imagens recordadas.

Portanto, nas teses damasianas, os componentes primordiais da mente são naturalmente as imagens, as imagens multissensoriais, que, como vimos nos pontos anteriores, defluem do nosso mundo visceral, em concatenação com os sentimentos que as acompanham. Além disso, nunca é demais lembrar que a memória trabalha recreativamente sobre elas. $E$ há também uma constante tradução desses fotogramas internos para a linguagem verbal, consignada numa track verbal contínua, um discurso interno permanente. Ou seja, há um texto Interno que acompanha as Imagens que nos chegam dos sujeitos e acontecimentos, internos e externos, e dos respectivos sentimentos. Saliente-se que todos nós usamos palavras nos nossos pensamentos, no nosso fluxo mental contínuo. Existe, por isso, uma evidente componente interna dialógica e narrativa.

Por sua vez, esses elementos, em conjunto e interação, consubstanciam-se naquilo que o neurocientista designa como o espetáculo multimidia do eu:

Para ter a experiência de assistir a um espetáculo de multimédia onde o Eu é o espetador, e onde, por vezes, até podemos assistir ao espetáculo de nos vermos a assistir ao espetáculo, não chega ter a subjetividade. Para que tal aconteça precisamos de outro componente: a integração de imagens e das respetivas [sic]

\footnotetext{
${ }^{14}$ Há quem discorde desta concepção e a ache demasiado reducionista, mas, grosso modo, ela é aceita entre a comunidade médico-científica.
} 
subjetividades num quadro mais ou menos vasto. A consciência, no mais pleno sentido do termo, é um estado mental particular em que as imagens mentais estão imbuídas de subjetividade e são experienciadas num quadro integrado (DAMÁSIO, 2017, p. 215).

A nossa consciência é formada, camada por camada, pela narrativa de vida de cada um. A história dos acontecimentos e objetos no filme da nossa vida são importantíssimos, mas o modo como os contamos a nós próprios ainda é mais, pois as imagens, onde eles estão impressos, são filtradas pelos nossos sentimentos e pela nossa perspectiva. Somos, sem dúvida, os realizadores, os narradores, do nosso filme interior. Como é evidente, existem diferenças notórias entre o trabalho de realização cinematográfica e o labor da consciência. Por exemplo: a feitura de um filme implica um trabalho coletivo, de equipe; depende também dos meios de produção; e os próprios suportes físicos - sobretudo, se nos reportarmos à época pré-digital - sofrem desgaste. Além disso, e talvez seja esta a antinomia mais assinalável, um realizador lida com materiais, essencialmente, de natureza ficcional, ao passo que a consciência, de algum modo, se consigna sobre elementos retirados do real - ainda que, amiúde, ficcione sobre eles. Porém, são também muitas as similitudes entre ambas as atividades, e são elas que mais importam realçar neste artigo. Continuemos, então, a analisar como é que tal se constitui.

Possuímos uma espécie de pessoalíssimo museu imagético interno ao qual podemos aceder sempre que quisermos; um arquivo fílmico-subjetivo do eu, uma cinemateca interior. É deste modo, por exemplo, que usamos amiúde imagens do passado para compreendermos um determinado objeto ou acontecimento presente ou mesmo futuro. Por exemplo, isso sucede quando conhecemos alguém e essa pessoa nos faz lembrar uma outra que fez parte do nosso passado: julgamo-la com base nisso.

Em suma, em conjunto, as imagens, os sentimentos, a memória e a faixa verbal, perspectivadas pela subjetividade e pela integração experiencial, criam, como diz Damásio, um filme cerebral: uma narração interna na qual somos simultaneamente espectadores e criadores. Este é um dos fatores que ajuda a perceber o porquê da humanidade ser tão sensível à Sétima Arte, pois, como 
tenho vindo a assinalar, a consciência humana também se configura como um continuum narrativo (ou vários continua narrativos) assente em imagens, palavras e sentimentos, tal como ocorre numa tela de cinema. Assim, o que se passa em uma tela de cinema tem uma extraordinária similitude com o que ocorre no âmago das nossas consciências, ecoa o que ocorre nos nossos processos íntimos de autossubjetivação.

A esse propósito e para concluir, leia-se o que diz o neurocientista, e repare-se como o seu discurso consubstancia uma concepção da consciência enquanto cinema:

Uma Memória de Imagens é absolutamente indispensável para que exista criatividade. (...) Quando falamos de memória em relação à Arte e à Criatividade tem muito a ver com a capacidade de representar memórias. $E$ aquilo que, de facto [sic], distingue a memória humana é o ser capaz de criar uma memória, que pode ser recuperada, que pode ser "recalled" duma forma imagética seja duma [sic] forma imagética sonora ou duma forma imagética visual. Grande parte do nosso mundo atual é dominado por memórias ou visuais ou auditivas. (...) É a possibilidade de recuperar Imagens e a possibilidade de manipular Imagens que são a fonte principal da execução criativa. $E$, aqui, Metáforas do Cinema ajudam muito porque, tanto no que diz respeito ao som, como no que diz respeito à arte visual, o que acontece é que as imagens podem ser cortadas aos bocados. Quando nós falamos de montagem é exatamente isso. É a possibilidade de agarrar numa imagem e de levar a imagem mais para a frente ou mais para trás, no caso duma [sic] imagem visual, e cortá-la aos bocados, juntá-la diferentemente no tempo. E é essa verdadeiramente a base fundamental da criação artística, quer seja a criação que acontece para o escritor, ou a criação do dramaturgo, do cineasta ou do compositor (que está, no fundo, a criar imagens que ocorrem no tempo, e que são ligadas duma forma muito gentil, muito "smooth", ou duma forma muito shop!! [gesto de cortar]). Tudo está, de facto [sic], cortado aos bocados. Criatividade, memória e imaginação são capacidades interligadas, sem as quais não é possível conceber novos modelos, conceber novas realizações, quer do ponto de vista social, quer do ponto de vista das artes clássicas, ou da invenção filosófica: todas elas estão ligadas a essa imaginação (DAMÁSIO, 2017a). 


\section{Referências}

ACKERMAN, J. The genius of birds. New York, London: Pinguin Books, 2017.

CHALMERS, D. J. The conscious mind: in search of a theory of conscious experience. Oxford: Oxford University Press, 1996.

DAMÁSIO, A. O livro da consciência: a construção do cérebro consciente. Trad. de Luís Oliveira Santos/João Quina Edições. 1. ${ }^{a}$ edição. Lisboa: Temas e Debates/ Círculo de Leitores, 2010.

O sentimento de si: corpo, emoção e consciência. Versão portuguesa a partir do original em Inglês revista e anotada pelo autor. $1 .^{a}$ edição. Lisboa: Temas e Debates/ Círculo de Leitores, 2013. [1999] /

A estranha ordem das coisas: a vida, os Sentimentos e as culturas humanas. Trad. de Luís Oliveira Santos/João Quina Edições. 1. ${ }^{a}$ edição. Lisboa: Temas e Debates/ Círculo de Leitores, 2017.

Entrevista a António Damásio para as Fronteiras do Pensamento. Fronteiras do Pensamento, 2017a. Disponível em: https://www.youtube.com/watch? v=Slj3hOMallM.

DAMÁSIO, A.; KAPLAN, J.; MAN, K. Decoding the neural representation of story meanings across languages. Human Brain Mapping, September. 2017. Disponível em: http://morteza-dehghani.net/wp-content/uploads/Dehghani_et_al-2017-Human_Brain_ Mapping.pdf.

DENNETT, D. C. Consciousness explained. New York, Boston, London: Back Bay Books/Little Brown and Company, 1992.

From bacteria to Bach and back: the evolution of minds. New York: penguin Random House, 2017.

EASTERLIN, N. The functions of literature and the evolution of extended mind. Edição especial da New Literary History n. ${ }^{\circ}$ 44.vol. 4, primavera, 2013, pp. 661-82.

FRANKL, V. E. Man's search for meaning: the classic tribute to hope from the holocaust. London: Ebury Publishing/Penguin Books, 2004.

GODFREY-SMITH, P. Outras mentes: o polvo, o mar e a origem profunda da consciência. Trad. de Pedro Garcia Rosado. 2. ${ }^{a}$ ed. Lisboa: Temas e Debates/Círculo de Leitores, 2017.

HERMAN, D. Narrative theory and the cognitive sciences. California: Center for the Study of the Language and Information, Stanford University, 2003.

Storytelling and the sciences of the mind. Cambridge: Mit Press/ Massachusetts Institute of Technology, 2013.

HOGAN, P. C. Cognitive science, literature and the arts: a guide for humanists. New York and London: Routledge, 2003.

The mind and its stories: narrative universals and human emotion. Cambridge: Cambridge University Press, 2003a. 
SEARLE, J. R. Da realidade física à realidade humana. Trad. Daniela Moura Soares. Lisboa: Gradiva, 2020.

SHELDRAKE, R. Dogs that know when their owners are coming home: and other unexplained powers of animals. New York: Three Rivers Press/Random House, 2011.

RECEBIDO: 30/06/2020

RECEIVED: 30/06/2020

Aprovado: 26/02/2021

Approved: 26/02/2021 